\title{
Evaluation of Rapid IgG4 Test for Diagnosis of Gnathostomiasis
}

\author{
Yue Wang ${ }^{1,2, *}$ (D) An Ma1', Xiao-Long Liu', Praphathip Eamsobhana ${ }^{3}$, Xiao-Xian Gan ${ }^{1, *}$ (]) \\ ${ }^{1}$ Institute of Parasitic Diseases, School of Basic Medical Sciences and Forensic Medicine, Hangzhou Medical College, Hangzhou, P. R. China; \\ ${ }^{2}$ National Institute of Parasitic Diseases, Chinese Centre for Disease Control and Prevention, Shanghai, P. R. China; ${ }^{3}$ Department of Parasitology, \\ Faculty of Medicine Siriraj Hospital, Mahidol University, Bangkok, Thailand
}

\begin{abstract}
Human gnathostomiasis is a parasitic disease caused by Gnathostoma nematode infection. A rapid, reliable, and practical immunoassay, named dot immuno-gold filtration assay (DIGFA), was developed to supporting clinical diagnosis of gnathostomiasis. The practical tool detected anti-Gnathostoma-specific lgG4 in human serum using crude extract of third-stage larvae as antigen. The result of the test was shown by anti-human IgG4 monoclonal antibody conjugated colloidal gold. The sensitivity and specificity of the test were both $100 \%$ for detection in human sera from patients with gnathostomiasis (13/13) and from healthy negative controls (50/50), respectively. Cross-reactivity with heterogonous serum samples from patients with other helminthiases ranged from 0 (trichinosis, paragonimiasis, clonorchiasis, schistosomiasis, and cysticercosis) to $25.0 \%$ (sparganosis), with an average of $6.3 \%$ (7/112). Moreover, specific lgG4 antibodies diminished at 6 months after treatment. This study showed that DIGFA for the detection of specific lgG4 in human sera could be a promising tool for the diagnosis of gnathostomiasis and useful for evaluating therapeutic effects.
\end{abstract}

Key words: Gnathostomiasis, diagnosis, DIGFA, IgG4

\section{INTRODUCTION}

Gnathostomiasis is a food-borne zoonosis caused by the infection of third-stage larvae (L3) of Gnathostoma spp. nematodes, which is commonly found in second-intermediate or paratenic hosts, such as freshwater fish, shellfish, frogs, and poultry $[1,2]$. The genus comprises 13 well-known species, 6 of which have been recorded for humans [3]. Gnathostomiasis is mainly endemic in Southeast Asia, where people consume raw or undercooked fish. In the past decade, increasing number of travellers returning from endemic areas and nonendemic natives who have eaten imported raw fish infected with Gnathostoma, developed gnathostomiasis.

Although isolation of Gnathostoma worms from the lesions they caused can make definitive diagnosis, it is rarely successful even in biopsies of cutaneous lesions due to larva's migration properties. In addition, biopsy is impractical for visceral infection. Alternatively, clinical symptoms, exposure history,

\footnotetext{
- Received 24 October 2020, revised 21 February 2021, accepted 23 February 2021.

*Corresponding authors (wangyuerr@hotmail.com; xxgan@zjams.com.cn)

(c) 2021, Korean Society for Parasitology and Tropical Medicine

This is an Open Access article distributed under the terms of the Creative Commons Attribution Non-Commercial License (https://creativecommons.org/licenses/by-nc/4.0) which permits unrestricted non-commercial use, distribution, and reproduction in any medium, provided the original work is properly cited.
}

and serological tests are being applied in combination in clinical diagnosis of human gnathostomiasis. Several serological test techniques have been utilized in different laboratories and immunoblot for detection through reaction with a Gnathostoma- specific $24 \mathrm{kDa}$ band is commonly used to confirm clinical diagnosis, with the highest specificity [4-7]. However, the immunoblot is labour-intensive and time-consuming, and requires sophisticated instruments and well-trained operators. Therefore, there is an urgent need for a rapid, reliable, and practical immunoassay for supporting clinical diagnosis of gnathostomiasis.

Specific antigens purified from native crude extracts or generated by genetic engineering methods, have been investigated for the diagnosis of gnathostomiasis [8-13]. Nevertheless, the preparation of these specific antigens is difficult for institutions without adequate health laboratory facilities in remote areas. In this study, we present a novel rapid immunoassay, dot immunogold filtration assay (DIGFA), to detect Gnathostoma-specific IgG4 in human serum using crude extract of L3 as antigen. In the present study, a preliminary evaluation for diagnostic sensitivity and specificity of this immunoassay was made, using serum samples from patients with gnathostomiasis, other helminthiases and normal healthy individuals. 


\section{MATERIALS AND METHODS}

\section{Ethics declarations}

All human serum samples were collected with written informed consent of the subjects or their guardians after verbal explanation of the study. The present study was approved by the Ethics Committee of Zhejiang Academy of Medical Sciences under the approval no. 2018-018 and National Institute of Parasitic Diseases, Chinese Centre for Disease Control and Prevention under the approval no. NIPD2011-009.

\section{Serum samples}

In the present study, 13 serum samples from patients with gnathostomiasis were collected from 2011 to 2015 in Mainland China, among whom 2 patients have received parasitological diagnosis and the other 11 patients were diagnosed based on the triad of clinical symptoms, exposure risk and positive reaction against Gnathostoma-specific 24-kDa band by immunoblot. In addition, 50 healthy negative controls were collected from healthy donors with no history of exposure to parasites and no indication of helminth infection according to a stool examination at the time of blood collection. Details on the serum samples used in the current study are provided in Table 1.

For assays on cross-reactivity, 112 sera were obtained from 3 groups of patients with other helminthiases. The first group consisted of 50 sera from nematodiasis: angiostrongyliasis cantonensis (20), trichinosis spiralis (15) and intestinal nematodiasis (15). The second group included 30 sera from trematodiasis: paragonimiasis westermani (10), schistosomiasis japonica (10), and clonorchiasis sinensis (10). The third grouped
32 sera from infection with larvae of cestode: cysticercosis (10), sparganosis mansoni (12), and echinococcosis (10). Patients infected with Schistosoma japonica, Paragonimus westermani, Clonorchis sinensis and intestinal nematodes (Ascaris lumbricoides, Trichuris trichiura, and hook worm) were confirmed by parasitological examination of stool using the Kato Katz method. Cases of angiostrongyliasis cantonensis, sparganosis mansoni and cysticercosis cellulosae were diagnosed based on computerized tomography scan, exposure history and specific serological tests. Patients with echinococcosis were confirmed with surgical observation.

\section{Preparation of crude antigen: L3 soluble extract}

The G. spinigerum crude extract of $\mathrm{L} 3$ was prepared as described previously [14] with minor modifications. The liver of freshwater eels were collected from farmers' markets, gently sheared with forceps at the laboratory, and subsequently digested with $1 \%$ pepsin solution $(\mathrm{pH} 2.0)$ at $37^{\circ} \mathrm{C}$ for $4 \mathrm{hr}$. About 500 live larvae were collected from the digested liver tissue under a dissecting microscope. The larvae were rinsed 3 times with sterile normal saline, then re-suspended in $3 \mathrm{ml}$ pre-cooled phosphate-buffered saline (PBS, $0.01 \mathrm{~mol} / \mathrm{L}$, pH7.2) [containing proteinase inhibitors in Complete ULTRA Tablets, EDTA-free which inhibits serine proteases, cysteine proteases, and aspartic proteases (Roche, Penzberg, Germany), and $5 \mathrm{mM} \mathrm{EDTA}$, and homogenized using a glass tissue grinder. The homogenate was sonicated at $20 \mathrm{kHz}$ for $5 \mathrm{~min}$ on an ice bath and centrifuged at $20,000 \times \mathrm{g}$ for $15 \mathrm{~min}$ at $4^{\circ} \mathrm{C}$. The supernatants were pooled as the $\mathrm{L} 3$ crude extract. The protein concentration was measured by a Bradford Coomassie Plus Protein Assay Reagent Kit (Pierce, Rockford, Illinois, USA)

Table 1. Rapid detection of specific IgG4 in human sera by DIGFA using G. spinigerum crude extract of L3 as antigen

\begin{tabular}{|c|c|c|c|}
\hline Group & Subject & No. of sera & Positive rate (\%) \\
\hline A & Gathostomiasis & 13 & 100 \\
\hline B & Negative healthy control & 50 & 0 \\
\hline \multirow[t]{10}{*}{ C } & Other helminthiases & 112 & 6.3 \\
\hline & Angiostrongyliasis & 20 & 10 \\
\hline & Intestinal nematodiases (ascariasis, Trichuriasis ancylostomiasis,) & 15 & 6.7 \\
\hline & Trichinosis & 15 & 0 \\
\hline & Cysticercosis & 10 & 0 \\
\hline & Echinococcosis & 10 & 10 \\
\hline & Sparganosis & 12 & 25 \\
\hline & Clonorchiasis & 10 & 0 \\
\hline & Paragonimiasis & 10 & 0 \\
\hline & Schistosomiasis & 10 & 0 \\
\hline
\end{tabular}


and estimated at $2.7 \mathrm{mg} / \mathrm{ml}$.

\section{ELISA}

Indirect ELISA was used to detect the levels of specific antiGnathostoma-IgG4 in human serum with L3 crude extract as antigen. Each well of a 96-well micro-plate was coated with $100 \mu \mathrm{l}(2 \mu \mathrm{g} / \mathrm{ml})$ of the L3 crude antigen in $0.05 \mathrm{M}$ carbonatebicarbonate buffer ( $\mathrm{pH} 9.6$ ) at $4^{\circ} \mathrm{C}$ overnight and blocked with $3 \%$ BSA solution at $37^{\circ} \mathrm{C}$ for $1 \mathrm{hr}$. The plates were washed 3 times and $100 \mu \mathrm{l}$ of serum samples at a 1:100 dilutions were added and incubated at $37^{\circ} \mathrm{C}$ for $1 \mathrm{hr}$. Following a second washing, $100 \mu \mathrm{l}$ of a mouse anti-human IgG4 horseradish peroxidase conjugated antibody at 1:1,000 dilutions (Thermo Fisher, Carlsbad, California, USA) was added and incubated at $37^{\circ} \mathrm{C}$ for $1 \mathrm{hr}$. The plates were finally washed 3 times then 100 $\mu$ of tetramethylbenzidine substrate solution was added and incubated at room temperature for $15 \mathrm{~min}$ to determine the binding enzymatic activity. The enzyme reaction was stopped with $50 \mu \mathrm{l}$ of $2 \mathrm{M} \mathrm{H}_{2} \mathrm{SO}_{4}$, and the optical density (OD) was measured at a wavelength of $450 \mathrm{~nm}$ using a microtitre plate reader (Bio-Rad, Hercules, California, USA). The mean OD plus $3 \times \mathrm{SD}$ of 50 healthy control serum samples was set as a positive cut-off value.

\section{Development of DIGFA for lgG4 detection from human sera}

The DIGFA comprised of test cassettes, colloidal gold conjugated with mouse anti-human IgG4 monoclonal antibody (McAb) and washing buffer. The test cassettes were assembled as previously described [16]. Two dots consisting of $0.5 \mu \mathrm{l}$ of human IgG4 $(0.1 \mathrm{mg} / \mathrm{ml})$ used as positive control and $0.5 \mu \mathrm{l}$ of $\mathrm{L} 3$ crude antigen $(1 \mathrm{mg} / \mathrm{ml})$ were put separately at the sides of "C" (positive control dot) and "T" (test dot) on the centre of nitrocellulose membrane (Fig. 1). For the preparation of antihuman IgG4-conjugated colloidal gold solution, $100 \mathrm{ml}$ of mono-disperse gold solution ( $\mathrm{pH} 8.5$ ) was obtained according to the method described previously [16]. Then, it mixed with $0.25 \mathrm{mg}$ of mouse anti-human IgG4 Fc antibody (Thermo fisher, Carlsbad, California, USA) by stirring. Tris-HCl $(0.02 \mathrm{~mol} /$ $\mathrm{L}$, $\mathrm{pH} 8.5$, containing $3 \%$ bovine serum albumin and $0.05 \%$ tween-20) was used as washing buffer.

Serum sample test was performed as described by Ma et al. [16] (Supplementary Fig. S1). First, 2 drops ( $\sim 00 \mu l)$ of washing buffer were added to the test well to block non-specific binding on the nitrocellulose membrane; second, $25 \mu \mathrm{l}$ of se-

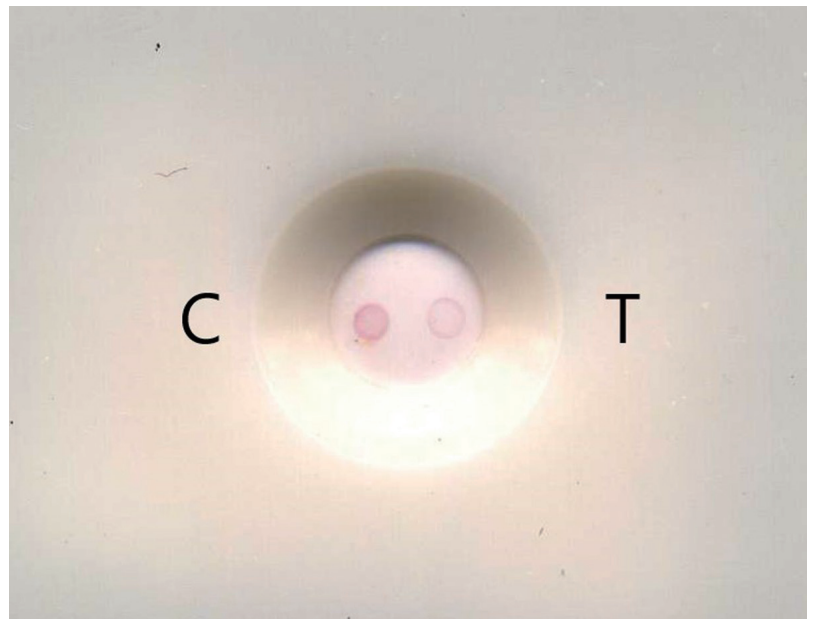

Fig. 1. Cassette for human lgG4 test by DIGFA displaying the result of a positive case. C, positive control dot; T, test dot.

rum sample was then added to flow through the membrane before one drop of washing buffer was added; third, one drop of the colloidal gold conjugate was added to visualize the specific antigen-antibody reaction before washing with another 2 drops of washing buffer; and finally observing the results with naked eyes. The appearance of a well-defined red dot at both sides of ' $\mathrm{T}$ ' and ' $\mathrm{C}$ ' in the test-well was considered to be positive; only one red dot appeared at the " $\mathrm{C}$ " side was considered negative; If a red dot did not appear at the side of ' $\mathrm{C}$ ', the test was invalid.

\section{Statistical Analysis}

The ELISA data were reported as the means of duplicated tests of each sample. Student's t-test was used to determine the significance of differences between data groups. A $P$-value less than 0.05 indicated statistical significance.

\section{RESULTS}

\section{Level of specific lgG4 in serum samples of patients with gnathostomiasis}

The mean OD value of patients with gnathostomiasis was significantly higher than that of patients with healthy controls $(t=6.791, P<0.01)$ and patients with other helminthiases $(t=6.779, P<0.01)$. There was no significant difference between mean OD values of patients with other helminthiases and healthy controls $(t=2.846, P>0.05)$ (Fig. 2). 


\section{Sensitivity and specificity of rapid DIGFA IgG4 test}

A total of 175 serum samples were tested for evaluation of rapid detection of specific IgG4 test. Results are summarized in Table 1. Rapid DIGFA IgG4 test using native L3 crude extract as antigen showed 100\% (13/13) sensitivity and 100\% (50/50) specificity for diagnosis of gnathostomiasis. Cross-reactivity with sera from patients with other helminthiases ranged from 0 (trichinosis, paragonimiasis, clonorchiasis, schistosomiasis, and cysticercosis) to $25 \%$ (sparganosis) with an average of $6.3 \%$ (7/112). Out of 7 serum samples with cross-activity, 4 samples showed weak reactions with light colour dots.

\section{Specific lgG4 antibody level in follow-up cases}

We have followed up 8 patients after treatment with single or multiple courses of albendazole and/or ivermectin. Posttreatment reduction in specific IgG4 levels for each patient was calculated by percentage, as follows: (1-post-treatment specificIgG4 level/pre-treatment specific-IgG4 level) × 100\%. Clinical

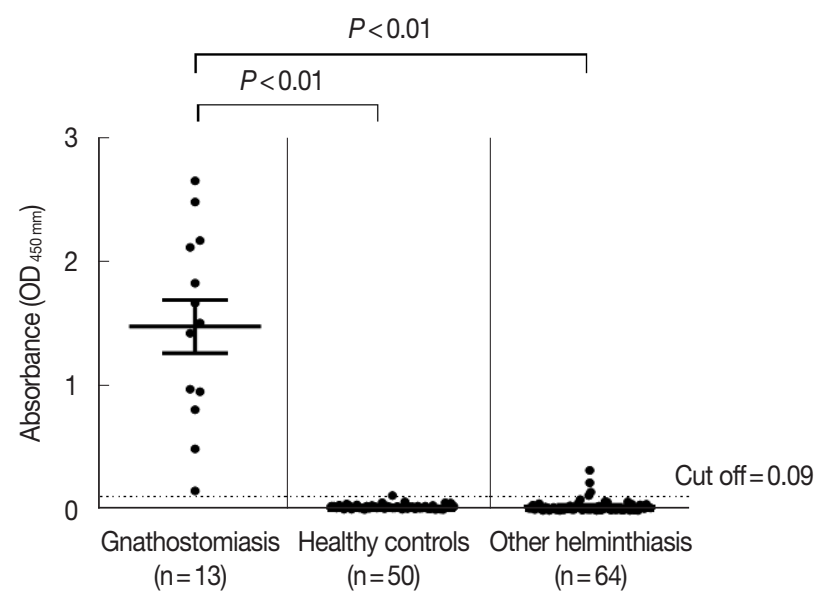

Fig. 2. Qualitative detection of specific IgG4 in human sera by rapid DIGFA. characteristics of the cases that have been followed up are summarised in Table 2. Two individuals (case 1,2) who have never relapsed after treatment showed significant reduction in specific IgG4 level but still over the cut-off threshold at 6 months post-treatment (Fig. 3A). This downtrend was well presented in DIGFA tests (Fig. 3C). In contrast, another 2 individuals (case 3,4) who suffered from failure treatments with recurrences, kept the same high levels of specific IgG4 as at pre-treatment when they were followed up at 6 months posttreatment (Fig. 3A, B).

Four patients (case 5-8) were followed up until 10 years after the initial treatment. Cases 5 and 6 complained suffering from intermittent recurrences after received multiple courses of albendazole. Both were specific IgG4 positive despite reductions of IgG4 levels by around 50\% (Fig. 3A, B). For both cases 7 and 8 , a G. spinigerum larva has been removed from their skin abscess (data not shown) during the first course of albendazole, and symptoms had never returned since then. Levels of specific IgG4 in their sera had fallen below the positive cut-off threshold and rapid DIGFA tests presented negative too (Fig. 3A, B).

\section{DISCUSSION}

IgG4 is known as an intriguing antibody with unique biological properties. Interaction between IgG4 and $\mathrm{Fc} \gamma \mathrm{Rs}$ is known to play an important role in host immune regulation of helminth infection $[17,18]$. In healthy population, IgG4 is the least represented IgG subclass, at less than $5 \%$ of total IgG. However, this odd immunoglobulin can rise to $50-95 \%$ of $\operatorname{IgG}$ and become the predominant antibody after human exposure to helminth antigens [17-19]. High concentration of IgG4 has been observed in the sera of patients with filariasis and the in-

Table 2. Clinical information and lgG4 test of eight gnathostomiasis follow-up cases

\begin{tabular}{|c|c|c|c|c|c|c|}
\hline \multirow{2}{*}{ Case } & \multirow{2}{*}{$\begin{array}{c}\text { Clinical } \\
\text { manifestation }\end{array}$} & \multirow{2}{*}{ Treatment } & \multirow{2}{*}{ Relapse } & \multirow{2}{*}{$\begin{array}{l}\text { IgG4 reduction } \\
\text { rate (\%) }\end{array}$} & \multicolumn{2}{|c|}{ DIGFA lgG4 test } \\
\hline & & & & & Pre-treatment & Post-treatment \\
\hline 1 & Visceral & Alb+lve & No & 23.1 & +++ & + \\
\hline 2 & Cutaneous & Alb & No & 58.7 & +++ & + \\
\hline 3 & Cutaneous & Alb & Yes & 0 & +++ & +++ \\
\hline 4 & Cutaneous & Alb & Yes & 2.90 & ++ & ++ \\
\hline 6 & Cutaneous & Ive & Yes & 54.7 & +++ & ++ \\
\hline 7 & Cutaneous & Alb & No & 41.8 & ++ & - \\
\hline 8 & Cutaneous & Alb & No & 89.6 & +++ & - \\
\hline
\end{tabular}

Alb, Albendazole; Ive, Ivermectin. 
A
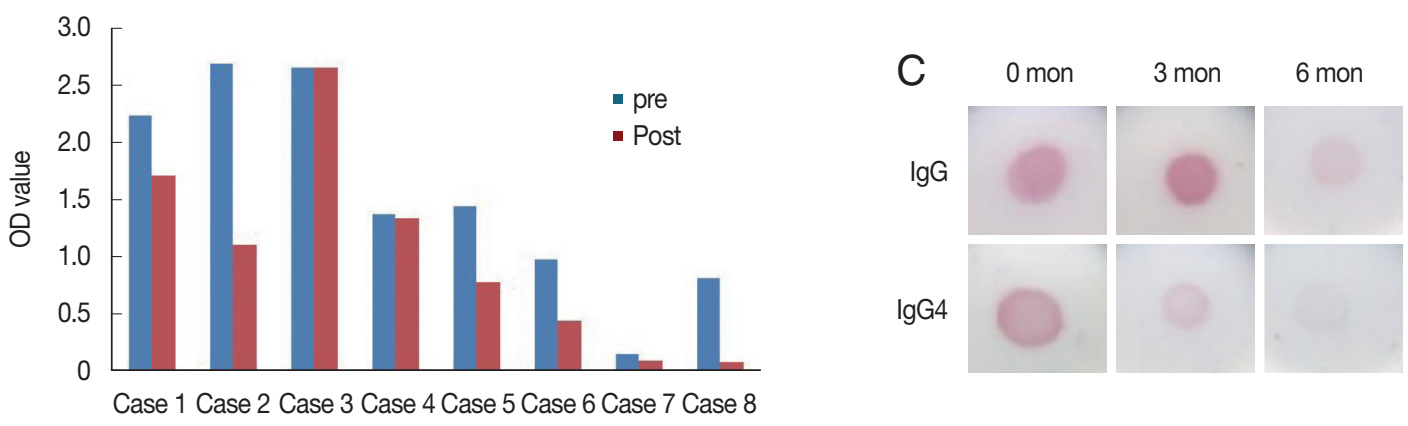

B
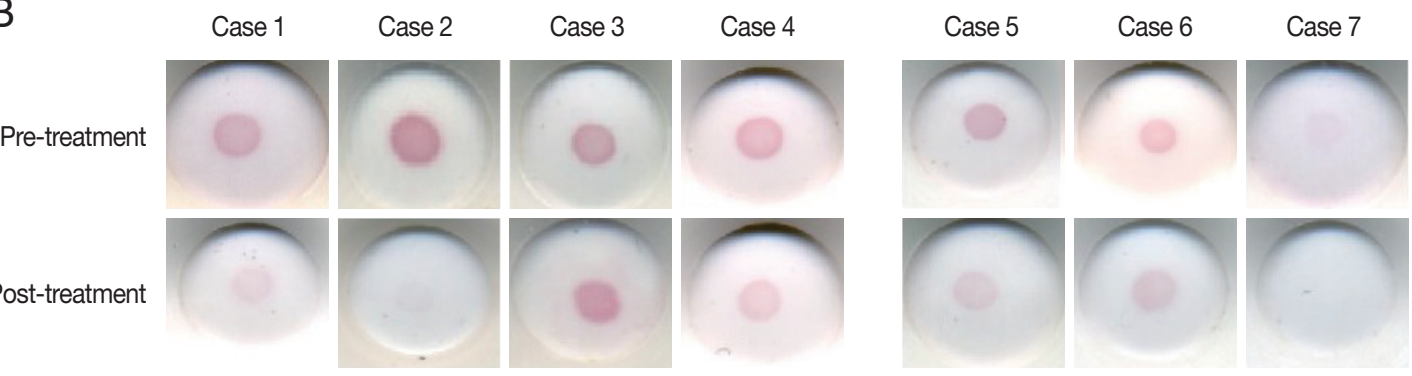

Case 8

Fig. 3. Detection of specific lgG4 in sera of patients after treatment. (A) Specific lgG4 in 8 paired sera of patients measured semi-quantitatively by ELISA. (B) Detection of specific lgG4 from 8 paired sera of patients using DIGFA. (C) IgG and lgG4 tests in sera from case 8 before treatment, and 3 and 6 months after treatment.

crease in specific IgG4 was positively correlated with microfilaremia $[20,21]$. Serological immunoassays to detect filarial-specific IgG4 have been successfully developed and applied for diagnosis of filariasis with high sensitivity and specificity [22, 23]. In human gnathostomiasis, IgG subclass antibodies have been qualitatively analysed by immunoblot and IgG4 has been identified as the predominant antibody in patient sera $[24,25]$. In this study, we first measured the levels of specific IgG4 against Gnathostoma L3 in serum samples by ELISA. Results showed that specific IgG4 levels in patients with gnathostomiasis were significantly higher than those of healthy controls and other helminthiases. This implied that specific IgG4 was a potential biomarker for diagnosis of human gnathostomiasis.

In this study, the rapid format DIGFA using L3 crude extract as antigen for detection of specific IgG4 against Gnathostoma presented $100 \%$ in both sensitivity and specificity for the diagnosis of gnathostomiasis, decreased cross-reactivity with other helminthiases, and increased specificity with respect to total IgG test by DIGFA [16]. The result of this study tallied with the data obtained previously by immunoblot analysis $[15,24,25]$. Specificity in sero-diagnosis of human helminthiasis could be enhanced by removing immune response to phosphocholine, carbohydrate, and polysaccharide antigens, which usually leads to false-positive reactions $[26,27]$. In our previous studies, the native $\mathrm{L} 3$ extract antigen-removed polysaccharide antigens by TCA/acetone precipitation had high specificity for gnathostomiasis diagnosis [16]. In this study, IgG4-based DIGFA using crude L3 extract attained similar diagnostic sensitivity and specificity as total IgG detection by DIGFA using partially purified L3 antigen.

Human gnathostomiasis has long been neglected and its immunological response characteristics still poorly understood. Albendazole and ivermectin are widely used to treat human gnathostomiasis with significant effectiveness, however the initial course is not always successful [28]. Recurrences are common from within a few weeks to years after chemotherapy, and 2 or more courses are needed in some cases [29-31]. Therefore, clinicians need a rapid test that detects biomarker of active infection or indication of cure to timely declare treatment success or failure. According to studies on serological diagnosis of filariasis, specific IgG4 response dramatically reduced then correlated with clearance of parasites, and high specific IgG4 level related with active infection [20]. As a same tissue dwelling nematode, Gnathostoma spp. worms might induce similar antibody response profile. According to the data of 8 patients' follow-up 6 months post treatment, significant reduction in specific IgG4 level coincided with successful treat- 
ment, indicating that such reduction is a promising indicator of effective treatment. However, this data is based on limited numbers of gnathostomiasis patients in China, and investigation on large-scale population is necessary to further prove the potential of specific IgG4 as an indicator of treatment efficacy. Better understanding of the dynamics of specific IgG4 responses in post-treatment patients is required for interpretation of follow-up data and more precise assessment of anti-helminth chemotherapy.

Unfortunately, due to the rarity of human gnathostomiasis, we were not able to collect enough serum samples from gnathostomiasis patients and pre/post-treatment paired samples. In the future, there is need to develop a model of infection with $G$. spinigerum worms in experimental animals and monitor the dynamic changes of specific antibodies after anti-helminth treatment. Another limitation from the current study is that there is no evidence to show the kit can distinguish species of Gnathostoma [32,33].

This study shows that DIGFA has high sensitivity and specificity to detect specific IgG4 in human sera. The test was not only more specific than detection of total IgG for the diagnosis of human gnathostomiasis, but also useful for evaluating therapeutic effects. Thus, this novel immunoassay is a promising tool for the diagnosis of gnathostomiasis.

\section{ACKNOWLEDGMENTS}

The authors would like to thank the Director of Zhejiang Academy of Medical Sciences for permission to conduct the present study. We thank Drs. Ganyu Xu and Kokouvi Kassegne for improving English-language presentation of this paper. This work was financially supported by the Medical Science \& Technology Project of Zhejiang Province (grant no. 2011 KY001), the Foundation of National Science and Technology Major Program (grant no. 2012ZX10004-220) and the Open Project of Key Laboratory of Parasite and Vector Biology, Ministry of Health (grant no. WSBKTKT201501).

\section{CONFLICT OF INTEREST}

The authors declare that they have no competing interests.

\section{REFERENCES}

1. Eamsobhana P, Wanachiwanawin D, Roongruangchai K, Song
SL, Yong HS. Genetic diversity of infective larvae of Gnathostoma spinizerum (Nematoda: Gnathostomatidae) in freshwater swamp eels from Thailand. J Helminthol 2017; 91: 767-771. https://doi. org/10.1017/S0022149X16000857

2. Daengsvang S. Gnathostomiasis in Southeast Asia. Southeast Asian J Trop Med Public Health 1981; 12: 319-332.

3. Diaz JH. Gnathostomiasis: an emerging infection of raw fish consumers in Gnathostoma nematode-endemic and nonendemic countries. J Travel Med 2015; 22: 318-324. https://doi.org/10.1111/ jtm.12212

4. Katchanov J, Sawanyawisuth K, Chotmongkoi V, Nawa Y. Neurognathostomiasis, a neglected parasitosis of the central nervous system. Emerg Infect Dis 2011; 17: 1174-1180. https://doi.org/10.3201/ eid1707.101433

5. Cornaglia J, Jean M, Bertrand K, Aumaitre H, Roy M, Nickel B. Gnathostomiasis in Brazil: an emerging disease with a challenging diagnosis. J Travel Med 2016; 24: 1-4. https://doi.org/10.1093/ jtm/taw074

6. Mulroy E, Simpson M, Frith R. Thoracic Myelopathy Due to Gnathostomiasis acquired in New Zealand. Am J Trop Med Hyg 2016; 95: 868-870. https://doi.org/10.4269/ajtmh.16-0283

7. Sharma C, Piyaphanee W, Watthanakulpanich D. Case report: clinical features of intermittent migratory swelling caused by gnathostomiasis with complete follow-up. Am J Trop Med Hyg 2017; 97: 1611-1615. https://doi.org/10.4269/ajtmh.17-0239

8. Nopparatana C, Setasuban P, Chaicumpa W, Tapchaisri P. Purification of Gnathostoma spinizerum specific antigen and immunodiagnosis of human gnathostomiasis. Int J Parasitol 1991; 21: 677-687. https://doi.org/10.1016/0020-7519(91)90079-m

9. Laummaunwai P, Intapan PM, Wongkham C, Lulitanond V, Tayapiwatana C, Maleewong W. Gnathostoma spinigerum: molecular cloning, expression and characterization of the cyclophilin protein. Exp Parasitol 2010; 126: 611-616. https://doi.org/10.1016/ j.exppara.2010.06.004

10. Campista-Leon S, Delgado-Vargas F, Landa A, Willms K, LopezMoreno HS, Mendoza-Hernandez G, Rios-Sicairos J, BojorquezContreras AN, Diaz-Camacho SP. Identification of immunodominant peptides from Gnathostoma binucleatum. Am J Trop Med Hyg 2012; 87: 888-896. https://doi.org/10.4269/ajtmh.2012.12-0233

11. Janwan P, Intapan PM, Yamasaki H, Laummaunwai P, Sawanyawisuth $\mathrm{K}$, Wongkham C, Tayapiwatana C, Kitkhuandee A, Lulitanond V, Nawa Y, Maleewong W. Application of recombinant Gnathostoma spinizerum matrix metalloproteinase-like protein for serodiagnosis of human gnathostomiasis by immunoblotting. Am J Trop Med Hyg 2013; 89: 63-67. https://doi.org/10.4269/ajtmh.12-0617

12. Janwan $P$, Intapan PM, Yamasaki H, Rodpai R, Laummaunwai P, Thanchomnang T, Sanpool O, Kobayashi K, Takayama K, Kobayashi Y. Development and usefulness of an immunochromatographic device to detect antibodies for rapid diagnosis of human gnathostomiasis. Parasit Vectors 2016; 9: 14-17. https:// doi.org/10.1186/s13071-016-1294-y

13. Janwan P, Intapan PM, Laummaunwai P, Rodpai R, Wongkham 
C, Insawang T, Thanchomnang T, Sanpool O, Maleewong W. Proteomic analysis identification of antigenic proteins in Gnathostoma spinigerum larvae. Exp Parasitol 2015; 159: 53-58. https://doi.org/10.1016/j.exppara.2015.08.010

14. Dharmkrong-at A, Migasena S, Suntharasamai P, Bunnag D, Priwan R, Sirisinha S. Enzyme-linked immunosorbent assay for detection of antibody to Gnathostoma antigen in patients with intermittent cutaneous migratory swelling. J Clin Microbiol 1986; 23: 847-851. https://doi.org/10.1016/j.exppara.2015.08.010

15. Laummaunwai $P$, Sawanyawisuth K, Intapan PM, Chotmongkol V, Wongkham C, Maleewong W. Evaluation of human IgG class and subclass antibodies to a $24 \mathrm{kDa}$ antigenic component of Gnathostoma spinigerum for the serodiagnosis of gnathostomiasis. Parasitol Res 2007; 101: 703-708. https://doi.org/10.1007/ s00436-007-0538-3

16. Ma A, Wang Y, Liu XL, Zhang HM, Eamsobhana P, Yong HS, Gan XX. A filtration-based rapid test using a partially purified third-stage larval antigen to detect specific antibodies for the diagnosis of gnathostomiasis. J Helminthol 2019; 93: 26-32. https://doi.org/10.1017/S0022149X17001080

17. Davies AM, Sutton BJ. Human IgG4: a structural perspective. Immunol Rev 2015; 268:139-159. https://doi.org/10.1111/imr.12349

18. McSorley HJ, Maizels RM. Helminth infections and host immune regulation. Clin Microbiol Rev 2012; 25: 585-608. https:// doi.org/10.1128/CMR.05040-11

19. Aalberse RC, Stapel SO, Schuurman J, Rispens T. Immunoglobulin G4: an odd antibody. Clin Exp Allergy 2009; 39: 469-477. https://doi.org/10.1111/j.1365-2222.2009.03207.x

20. Adjobimey T, Hoerauf A. Induction of immunoglobulin G4 in human filariasis: an indicator of immunoregulation. Ann Trop Med Parasitol 2010; 104: 455-464. https://doi.org/10.1179/1364 85910X12786389891407

21. Prodjinotho UF, von Horn C, Debrah AY, Batsa Debrah L, Albers A, Layland LE, Hoerauf A, Adjobimey T. Pathological manifestations in lymphatic filariasis correlate with lack of inhibitory properties of IgG4 antibodies on IgE-activated granulocytes. PLoS Negl Trop Dis 2017; 11: e0005777. https://doi.org/10.1371/journal.pntd.0005777

22. Dieye Y, Storey HL, Barrett KL, Gerth-Guyette E, Di Giorgio L, Golden A, Faulx D, Kalnoky M, Ndiaye MKN, Sy N, Mané M, Faye B, Sarr M, Dioukhane EM, Peck RB, Guinot P, de Los Santos T. Feasibility of utilizing the SD BIOLINE Onchocerciasis IgG4 rapid test in onchocerciasis surveillance in Senegal. PLoS Negl Trop Dis 2017; 11: e0005884. https://doi.org/10.1371/journal.pntd.0005884

23. Steel C, Golden A, Kubofcik J, LaRue N, de Los Santos T, Domingo
GJ, Nutman TB. Rapid Wuchereria bancrofti-specific antigen Wb123based IgG4 immunoassays as tools for surveillance following mass drug administration programs on lymphatic filariasis. Clin Vaccine Immunol 2013; 20: 1155-1161. https://doi.org/10.1128/CVI.0025213

24. Anantaphruti MT, Nuamtanong S, Dekumyoy P. Diagnostic values of IgG4 in human gnathostomiasis. Trop Med Int Health 2005; 10: 1013-1021. https://doi.org/10.1111/j.1365-3156.2005.01478.x

25. Zambrano-Zaragoza JF, Duran-Avelar Mde J, Messina-Robles M, Vibanco-Perez N. Characterization of the humoral immune response against Gnathostoma binucleatum in patients clinically diagnosed with gnathostomiasis. Am J Trop Med Hyg 2012; 86: 988-992. https://doi.org/10.4269/ajtmh.2012.11-0741

26. Lal RB, Dhawan RR, Tarrand JJ, Ayoub EM, Ottesen EA. Lack of IgG4 antibody response to carbohydrate antigens in patients with lymphatic filariasis. Immunology 1991; 74: 333-337.

27. Lal RB, Ottesen EA: Enhanced diagnostic specificity in human filariasis by IgG4 antibody assessment. J Infect Dis 1988, 158:1034-1037. https://doi.org/10.1093/infdis/158.5.1034.

28. Herman JS, Chiodini PL. Gnathostomiasis, another emerging imported disease. Clin Microbiol Rev 2009; 22: 484-492. https:// doi.org/10.1128/CMR.00003-09

29. Strady C, Dekumyoy P, Clement-Rigolet M, Danis M, Bricaire F, Caumes E. Long-term follow-up of imported gnathostomiasis shows frequent treatment failure. Am J Trop Med Hyg 2009; 80: 33-35. https://doi.org/10.4269/ajtmh.2009.80.33

30. Maco V, Bravo L, Marcos LA. Recurrent abdominal panniculitis in a Peruvian man. Int J Dermatol 2016; 55: 1057-1059. https:// doi.org/10.1111/ijd.13107

31. Paran Y, Brufman T, Shehadeh W, Katz O. Swelling of the right cheek in an Israeli traveler returning from Columbia: a diagnostic challenge. Travel Med Infect Dis 2017; 19: 72. https://doi. org/10.1016/j.tmaid.2017.08.009

32. Neumayr A, Ollague J, Bravo F, Gotuzzo E, Jimenez P, Norton SA, Doanh PN, Nawa Y, Horii Y, Nickel B, Marti H. Cross-reactivity pattern of Asian and American human gnathostomiasis in Western blot assays using crude antigens prepared from Gnathostoma spinigerum and Gnathostoma binucleatum third-stage larvae. Am J Trop Med Hyg 2016; 95: 413-416. https://doi.org/10.4269/ ajtmh.16-0176

33. Nawa Y, Maleewong W, Intapan PM, Díaz-Camacho SP. Gnathostoma. In Xiao L, Ryan U, Feng Y eds, Biology of Foodborne Parasites. Boca Raton, USA. CRC Press. 2015, pp 405-425. 
